such as the worship of ancestors, is one of the finest of the few which exist outside the Peiping Palace collections, and is otherwise remarkable in that it has four handles. It is highly ornamented with conventionalised designs including elephant heads and, possibly, stylised tigers. It has an inscription of sixty-nine characters, which is perfectly legible, though interpretations vary. The bowl would appear to commemorate a grant of land, for services rendered, to the Marquis Hsing by an emperor, conjecturally identified as Ch'êng (1115-1078 B.c.) The group of three painted bricks form a pediment which comes from a Han tomb. On them is a free and spirited symbolical design which is here interpreted as expressing the form taken by the Taoistic belief in life after death under that dynasty.

\section{The Typhoon of September 21, 1934, in Japan}

WHAT is described as the greatest typhoon on record struck the southern coast of Japan early on September 21. A week later, the Earthquake Research Institute sent several of its members to the district, and their reports on various features of the typhoon are included in a special volume of the Institute's Bulletin (Suppl. vol. 2, 302 pp. and 34 pls.). All the nine memoirs are written in Japanese, but, with two exceptions (mainly in tabular form), they are followed by summaries in English. The typhoon was generated at sea, in about lat. $11^{\circ} \mathrm{N}$., long. $141^{\circ} \mathrm{E}$., on September 13. It was then weak, and travelled slowly towards the north-west. A week later, near the Ryukyu Islands, its course changed to northeast. When it reached Sikoku, on the southern coast of Japan, its centre showed a pressure of $22.4 \mathrm{in}$., probably a record for land stations. The typhoon then passed over the adjoining districts, causing much damage to houses and trees, but it is worthy of notice that some earthquake-proof school buildings withstood a gale of 134 miles an hour. The main damage occurred in the coastal districts, and was due partly to the sea-waves, or kaze-tunami, raised by the typhoon and partly to a sudden rise of the sea that at Osaka ranged from $9 \cdot 5$ to $18 \cdot 7 \mathrm{ft}$., and at Kobe from $5 \cdot 8$ to $6 \cdot 5 \mathrm{ft}$. Among the causes of this abnormal rise, Mr. R. Takahasi includes a suction-like action on the sea-water due to the low pressure in the centre of the typhoon-path and the drift of the water to the coast by the force of the winds. Farther on, the typhoon passed over Lake Biwa, generating seiches with amplitudes of $10 \mathrm{in.}$ and a rise of the same amount in the northern half of the lake, due again to the drift of the water. Even in the neighbourhood of Tokyo, the sea-level rose by about $4 \mathrm{ft}$.

\section{British Association Seismological Committee}

During the past year, the Committee has lost two of its members, Sir Horace Lamb and Prof. H. M. Macdonald. Two former members, Sir Alfred Ewing and Sir Arthur Schuster, also died since the last report was issued. The year has been marked by the publication of some important memoirs by members of the Committee. Two of them are on microseisms by Mr. A. W. Lee, who has shown that the average amplitudes of the east and vertical components of the microseisms recorded at Kow in 1932 were equal. and that microseisms usually approach England from the north-west, and are associated with storms in the Atlantic. A valuable memoir on the times of transmission of earthquake waves by Dr. H. Jeffreys and Mr. K. E. Bullen has been published by the International Seismological Association (Trav. Scie., Sec. A, Fasc. 11 ; 1935), the inclusion of the summaries for individual earthquakes having been rendered possible by a grant from the Gray-Milne fund. A new catalogue of earthquakes, for the years 1925-30, has been prepared by Miss E. F. Bellamyfrom the International Seismological Summary. The form is the same as in the earlier number for 1918-24, edited by Prof. Turner, of which it is a welcome and very useful continuation. The International Seismological Summary for the first quarter of 1931 is in the press.

\section{River Dee (Aberdeenshire) Flow Records}

THE private organisation under the direction of Capt. W. N. MeClean, known as River Flow Records, has continued its survey of the River Dee, under. taken in connexion with the British Association meeting at Aberdeen in September last year, and has recently issued two sheets of diagrams covering the period January-June inclusive of this year, together with an explanatory memorandum which states that the diagrams represent readings of waterlevels and river flows from a catchment area of 528 square miles, and that they include meteorological records of rainfall, temperature and wind over the same district. As the result of the study of these observations of the Dee area, which have now been kept for a year and a half, it is found that in a comparison of rainfall and run-off, the former is underestimated. There is no actual measurement on the high mountains, and it may be said that rainfall measured in a rain-gauge is generallyunder-estimated; so that rainfall is admittedly only an approximation, whereas the measurement of flow by means of 'the most perfect apparatus existing in the country' is comparatively accurate. In the six months' period, the net aggregate of storage and run-off has reached just less than 19 in. out of a gross rainfall of $22 \frac{1}{2}$ in.

\section{Electric Progress in Palestine}

Lord Reading, the chairman of the Palestine Electric Corporation, said at the annual general meeting on September 5 that electricity has played a leading part in the rapid economic development of Palestine. Last year the Corporation's revenue increased by 64 per cent, and 13,460 new consumers were connected. The generating plant now exceeds 40,000 kilowatts, and the existing transmission line from the first Jordan power house to Tel-Aviv will, at the present rate of growth, soon become inadequate to meet the consumers' load. Hence, a $12,000 \mathrm{kw}$. turbo-generator with the requisite boiler plant, transformers and switchgear has been ordered, and a second 66,000 kilovolt-transmission line will be 
constructed. On the upper reaches of the River Jordan and Lake Tiberias, surveys are being carried out with the view of further hydroelectric development. Lord Reading stated that the demands in the Corporation's area are still far from the saturation point. As the policy of reducing tariffs wherever possible is being continued, the prospects are promising. As Palestine is practically a 'new' country from the economic point of view, it is not surprising that the company is already on a remunerative basis.

\section{Sedimentation}

Bulletin 98 of the National Research Council of America (1935, pp. 246) embodies the report of the Committee on Sedimentation for 1932-34, and indicates the immense activity of investigators in this subject as well as of the members responsible for the report. The latter includes about a thousand references to current literature and in itself represents a commendable example of bibliographic and abstracting work. The topics discussed include European studies and varved sediments (Antevs); German contributions (Becker); studies at Stanford University (Blackwelder); glacial sediments (Leighton and Townley); British researches (Milner); mineralogy of sediments (Pettijohn); hydrologic and hydrographic investigations (Piper); chemical aspects (Steiger); recent sediments and petroleum sourcebeds (Trask); miscellaneous types (Twenhofel); marine bottom deposits (Vaughan); oxidationreduction conditions in the Gulf of Catalina ( $\mathrm{ZoBell}$ ); and terminology of coarse sediments (Wentworth, with notes by Boswell). The last of these is a contribution of very general interest. The Sub-committee on Nomenclature and Classification of Sediments is studying the terminology of eleven groups, and in his introduction to the present report, Trowbridge holds out the prospect that following up the two reports already issued on volcanic and coarse sediments, others may be expected at the rate of two or more per year. The Committee is to be congratulated on the thoroughness of its work. It is obvious that without such a review geologists could not possibly keep in touch with the widely varied results of current progress in a branch of their science which is fundamental to its main object and to many of its applications.

\section{Mining Legislation in South Australia}

WE have received from the South Australian Department of Mines the Mining Review, No. 61, for the half-year ended December 31, 1934. After a short preface signed by Dr. L. Keith Ward, director of mines and also Government geologist, whose report appears afterwards, the review contains a summary of mining legislation, etc. A statistical portion which, together with a table at the end of the volume, shows that the total value of the minerals produced in South Australia since 1841 up to the end of 1934 equals 53t million pounds, taking gold at its old value. They also show a considerable increase both in quantity and value in 1934 compared to 1933, the quantity of iron ore produced in the former year being practically $1 \frac{1}{4}$ million tons, showing an increase of half a million tons over 1933 . Gold has naturally increased both in quantity and in value, and most other minerals show increases, though these in some cases are but slight, and actually show decreases in a few cases. Next comes a statement as to subsidies, from which it would appear that the amount advanced to various mines is nearly $£ 71,000$, of which a little more than $£ 18,000$ has been repaid. Next we have certain reports of treatment works and Government boring operations, followed by a short report by the Government geologist, and a series of reports by the chief inspector of mines, which give much detailed information about many of the mines of the Province.

\section{Research on Shellac}

IN 1925, the Indian Government founded the Lac Research Institute to ensure that the rapid development of rival products, and the high price levels reached in the post-War period, did not cause lac to meet the same fate that indigo had suffered previously. The results obtained during the first nine years work of the Institute and the present trend of the investigations have recently been published as an illustrated booklet in concise, interesting and non-technical form ("Lac and the Indian Lac Research Institute", by D. Norris, P. M. Glover and R. W. Aldis. Nankum: Lac Research Institute. Rs. 2.8). The lac insect yields both a colouring matter and a resin, and it was for the former product that it was originally cultivated. With the discovery of aniline dyes, however, the lac dye industry came to an end and the resin in unmanufactured form as lac, or the manufactured form as shellac, became the important feature of the industry. The uses to which shellac can be put are numerous, but the greatest proportion is adsorbed by the gramophone, electrical and varnish trades. The increasing use of synthetic resins such as bakelite inevitably threatened the industry, but as new methods have now been discovered whereby the natural product may be used in combination with the synthetic, the situation has improved. Research work is carried out on entomological, chemical and biochemical lines, many problems naturally occurring with regard to the insect and its host plant as well as the secretion of lac and its preparation for the market.

\section{All-India Institute of Hygiene and Public Health}

IN the annual report of the All-India Institute of Hygiene and Public Health, Calcutta, for 1934, the first to be issued, the events which led to the foundation of an All-India Institute of Hygiene are first recapitulated. The conception of providing courses of post-graduate training in public health originated with Sir Leonard Rogers, and as a result of his efforts the Calcutta School of Tropical Medicine was founded and opened in 1920. It was realised that there was also need for the training of an Indian personnel in public health, but circumstances prevented the realisation of this object until the Rockefeller Foundation offered to provide funds for a site, and for the 